\title{
Coral Sclerochronology: Similarities and Differences in the Coral Isotopic Signatures Between Mesophotic and Shallow-Water Reefs
}

\author{
Tsuyoshi Watanabe, Takaaki K. Watanabe, \\ Atsuko Yamazaki, Shiori Yoneta, Kohki Sowa, \\ Frederic Sinniger, Gal Eyal, Yossi Loya, and Saki Harii
}

\begin{abstract}
Coral sclerochronology is a powerful tool for understanding environmental and ecological changes on coral reefs. Geochemical, isotopic, and skeletal density banding analyses along the major growth axis of massive coral skeletons from tropical shallow-water reefs have been used successfully to reconstruct decadal- to centennial-scale histories of climate and coral growth with annual to seasonal resolution. However, little is known about how coral sclerochronological approaches could capture environmental and/or physiological changes in mesophotic coral ecosystems (MCEs), which occur at depths ranging from 30 to $150 \mathrm{~m}$. We compared the oxygen and carbon isotopes and growth records of coral from upper MCEs with those from adjacent shallow reefs by examining Porites corals
\end{abstract}

T. Watanabe $(\varangle) \cdot$ A. Yamazaki

Department of Natural History Sciences, Hokkaido University,

Sapporo, Japan

Kikai institute for coral reef sciences, Kagoshima, Japan

e-mail: nabe@sci.hokudai.ac.jp

T. K. Watanabe $\cdot$ S. Yoneta $\cdot$ K. Sowa

Department of Natural History Sciences, Hokkaido University,

Sapporo, Japan

F. Sinniger $\cdot$ S. Harii

Tropical Biosphere Research Center, University of the Ryukyus, Motobu, Okinawa, Japan

G. Eyal

George S. Wise Faculty of Life Sciences, School of Zoology,

Tel Aviv University, Tel Aviv, Israel

The Interuniversity Institute for Marine Sciences in Eilat, Eilat, Israel

The Steinhardt Museum of Natural History, Israel National Center for Biodiversity Studies, Tel Aviv, Israel

Y. Loya

George S. Wise Faculty of Life Sciences, School of Zoology,

Tel Aviv University, Tel Aviv, Israel collected at 4 and $40 \mathrm{~m}$ from Okinawa, Japan, and from 5 and $50 \mathrm{~m}$ water depths from the Gulf of Eilat, Red Sea, Israel. Porites corals in MCEs exhibited low calcification rates, but still recorded distinct seasonal to interannual variability in oxygen and carbon isotope signals consistent with coral isotopic records on shallow reefs. The amplitudes of the seasonality in the isotopic records in corals from MCEs were larger than those expected from seasonal environmental variations and those recorded in shallow reefs, indicating that coral growth rate and/or physiological changes affected skeletal isotopic composition. Our results suggest that sclerochronological records have great potential for reconstructing environmental and ecological characteristics of MCEs. The isotopic records of MCE corals are also more influenced by physiological processes such as symbiotic photosynthesis, calcification rates, and trophic levels than their shallow-water counterparts.

\section{Keywords}

Coral sclerochronology $\cdot$ Oxygen isotope $\cdot$ Carbon isotope $\cdot$ Mesophotic coral ecosystems $\cdot$ Porites corals

\subsection{Introduction}

Symbiotic scleractinian reef-building corals ("corals" hereafter) occur in a range of environments from shallow-water coral reefs to depths $>150 \mathrm{~m}$ (Kahng et al. 2010). Mesophotic coral ecosystems (MCEs) occur at depths ranging from $30-40$ to $150 \mathrm{~m}$, where photosynthetically active radiation (PAR; 400-700 nm) is limited (Loya et al. 2016). Corals continuously accumulate calcium carbonate skeletons as they grow, providing a record of environmental conditions throughout the life span of the colony. Coral sclerochronology, a combined approach using physical and chemical 
analyses along the major growth axis, can provide a wealth of information about the environmental and physiological changes experienced by corals hundreds of years old (e.g., Gagan et al. 2000; Grottoli and Eakin 2007; Abram et al. 2016). Isotopic, geochemical, and skeletal growth analyses of certain massive corals (e.g., Porites and Orbicella) in tropical shallow reefs have been successfully used to reconstruct seasonal- to century-scale variation in environmental parameters (e.g., temperature, salinity, light intensity, nutrient dynamics, marine pollution, and ocean $\mathrm{pH}$ ) and coral growth (e.g., skeletal density, linear extension rate, and calcification rates) (see Table 36.1 and associated references).

The stable oxygen isotope ratio $\left({ }^{18} \mathrm{O}\right)$ in shallow-water corals is widely used to reconstruct sea surface temperature (SST) and sea surface salinity (SSS) (Table 36.1). The $\delta^{18} \mathrm{O}$ in the carbonate minerals that comprise the coral skeleton reflects both the water temperature and the chemical composition of the surrounding seawater (Epstein et al. 1953). Coral $\delta^{18} \mathrm{O}$ is biologically mediated and precipitated under isotopic disequilibrium from seawater $\delta^{18} \mathrm{O}$ (Weber and Woodhead 1970); however, the offset from equilibrium is assumed to be relatively constant within the same coral species. Carbon isotope ratios $\left(\delta^{13} \mathrm{C}\right)$ preserved in coral skeletons have also been used as an indicator for environmental parameters such as sunlight and dissolved inorganic carbon (DIC) (Table 36.1), although the factors controlling coral $\delta^{13} \mathrm{C}$ are more complicated due to the complex pathways and sources of carbon from the ambient seawater to the coral skeletons (Table 36.1).

Reef-building (symbiotic algae bearing) corals are typically associated with shallow-water habitats, but many species also occur in MCEs at water depths $>30-40 \mathrm{~m}$. MCEs have received increasing attention in recent years because of their potential to act as refuges for shallow-water coral reef taxa (Glynn 1996; Bongaerts et al. 2010; Loya et al. 2016) especially as shallow reefs become increasingly impacted by the changing global climate system, such as mass bleaching events (Hughes et al. 2017, 2018) and more intense tropical cyclones (Cheal et al. 2017). Sclerochronological approaches combined with geochemical analyses and growth characteristics in massive corals with depth provide an opportunity to identify historical environmental conditions and potentially environmental stress by analyzing key demographic indicators (e.g., extension rates, skeletal densities, calcification rates, and isotopic records in coral skeletons) in mesophotic corals. Numerous studies have examined the influence of depth on growth characteristics of massive corals (reviewed by Lough and Cooper 2011), but only a small number of studies from a single location (Gulf of Eilat, Red Sea) have examined the geochemical characteristics of mesophotic corals (Huston 1985; Klein et al. 1993; Al-Rousan et al. 2003; Rosenfeld et al. 2003). MCEs worldwide are poorly studied, and their long-term ecological dynamics remain virtually unknown (Loya et al. 2016).
Table 36.1 Summary of published coral geochemical and isotopic parameters and their environmental interpretation and coral growth histories

\begin{tabular}{|c|c|c|}
\hline Proxy & Controlling factor & References \\
\hline \multicolumn{3}{|c|}{ Isotopes } \\
\hline \multirow[t]{4}{*}{$\delta^{18} \mathrm{O}$} & $\begin{array}{l}\text { Sea surface } \\
\text { temperature }\end{array}$ & \multirow{3}{*}{$\begin{array}{l}\text { Dunbar and Wellington } \\
\text { (1981), Klein et al. (1992), } \\
\text { Cole et al. (1993), Dunbar } \\
\text { et al. (1994), Gagan et al. } \\
\text { (2000), Tudhope et al. } \\
\text { (2001), Felis et al. (2000), } \\
\text { Watanabe et al. (2003), and } \\
\text { Correge et al. (2004) }\end{array}$} \\
\hline & Seawater & \\
\hline & $\begin{array}{l}\delta^{18} \mathrm{O} \text { (precipitation, } \\
\text { evaporation, sea } \\
\text { surface salinity) }\end{array}$ & \\
\hline & $\begin{array}{l}\text { Kinetic } \\
\text { fractionation }\end{array}$ & McConnaughey (1989b) \\
\hline \multirow[t]{3}{*}{$\delta^{13} \mathrm{C}$} & $\begin{array}{l}\text { Physiological } \\
\text { factors (e.g. } \\
\text { symbiont } \\
\text { photosynthesis and } \\
\text { host respiration, } \\
\text { spawning, internal } \\
\text { pH, feeding, trophic } \\
\text { level) }\end{array}$ & $\begin{array}{l}\text { Swart (1983), Muscatine } \\
\text { et al. (1989), } \\
\text { McConnaughey (1989a, b), } \\
\text { McConnaughey et al. } \\
\text { (1997), Grottoli and } \\
\text { Wellington (1999), and } \\
\text { Gagan et al. (1998) }\end{array}$ \\
\hline & $\begin{array}{l}\text { Environmental } \\
\text { factors (e.g., solar } \\
\text { irradiance, } \\
\text { dissolved inorganic } \\
\text { carbon, upwelling) }\end{array}$ & $\begin{array}{l}\text { Nozaki et al. (1978), Cole } \\
\text { and Fairbanks (1990), } \\
\text { Grottoli and Wellington } \\
\text { (1999), Reynaud-Vaganay } \\
\text { et al. (2001), Grottoli } \\
\text { (2002), and Watanabe et al. } \\
\text { (2017) }\end{array}$ \\
\hline & $\begin{array}{l}\text { Kinetic } \\
\text { fractionation }\end{array}$ & McConnaughey (1989b) \\
\hline$\delta^{11} \mathrm{~B}$ & $\mathrm{pH}$ & $\begin{array}{l}\text { Hönisch et al. (2004), } \\
\text { Reynaud et al. (2004), and } \\
\text { Trotter et al. (2011) }\end{array}$ \\
\hline$\delta^{15} \mathrm{~N}$ & $\begin{array}{l}\text { Inorganic nitrogen } \\
\text { sources }\end{array}$ & $\begin{array}{l}\text { Marion et al. (2005), } \\
\text { Yamazaki et al. (2011), and } \\
\text { Wang et al. (2015) }\end{array}$ \\
\hline \multicolumn{3}{|c|}{ Trace and minor elements } \\
\hline $\mathrm{Sr} / \mathrm{Ca}$ & $\begin{array}{l}\text { Sea surface } \\
\text { temperature }\end{array}$ & $\begin{array}{l}\text { Smith et al. (1979), Beck } \\
\text { et al. (1992), Alibert and } \\
\text { McCulloch (1997), Gagan } \\
\text { et al. (1998), Correge et al. } \\
\text { (2000), Tudhope et al. } \\
\text { (2001), Watanabe et al. } \\
\text { (2001), Marshall and } \\
\text { McCulloch (2002), } \\
\text { Stephans et al. (2004), Felis } \\
\text { et al. (2004), and Zinke } \\
\text { et al. (2004) }\end{array}$ \\
\hline $\mathrm{Mg} / \mathrm{Ca}$ & $\begin{array}{l}\text { Sea surface } \\
\text { temperature }\end{array}$ & $\begin{array}{l}\text { Mitsuguchi et al. (1996) } \\
\text { and Watanabe et al. (2001) }\end{array}$ \\
\hline \multirow[t]{2}{*}{$\mathrm{Ba} / \mathrm{Ca}$} & Upwelling & $\begin{array}{l}\text { Lea et al. (1989) and } \\
\text { Montaggioni et al. (2006) }\end{array}$ \\
\hline & River outflow & McCulloch et al. (2003) \\
\hline $\mathrm{P} / \mathrm{Ca}$ & $\begin{array}{l}\text { Phosphorus } \\
\text { concentrations, } \\
\text { upwelling }\end{array}$ & LaVigne et al. $(2008,2010)$ \\
\hline
\end{tabular}


Table 36.1 (continued)

\begin{tabular}{l|l|l}
\hline Proxy & Controlling factor & References \\
\hline $\begin{array}{l}\text { Skeleton } \\
\text { Skeletal } \\
\text { growth bands }\end{array}$ & $\begin{array}{l}\text { Density, extension } \\
\text { (growth) rates, } \\
\text { calcification rates, }\end{array}$ & $\begin{array}{l}\text { Knutson et al. (1972), } \\
\text { Dodge and Thomson } \\
\text { (1974), Dodge and Brass } \\
\text { (1984), Huston (1985), } \\
\text { Lough and Barnes (2000), } \\
\text { and Tortolero-Langarica } \\
\text { et al. (2016) }\end{array}$ \\
\hline $\begin{array}{l}\text { Luminescence } \\
\text { bands }\end{array}$ & Freshwater input, & $\begin{array}{l}\text { Scoffin et al. (1989), Klein } \\
\text { et al. (1990), Barnes and } \\
\text { Taylor (2001); Nyberg } \\
\text { (2002), Lough (2007, } \\
\text { 2011), and Grove et al. } \\
\text { (2010) }\end{array}$ \\
\hline
\end{tabular}

Here, we present $\delta^{18} \mathrm{O}$ and $\delta^{13} \mathrm{C}$ records reconstructed from the skeletons of the massive Porites corals collected from upper mesophotic depths (40-50 m) at Sesoko and Ie islands, Okinawa, Japan, and from Gulf of Eilat, Red Sea, Israel, and compare their geochemistry to Porites corals collected from adjacent shallow $(\sim 5 \mathrm{~m})$ reefs. We examine the similarities and differences in coral isotopic signatures between MCEs and shallow reefs and assess the potential for using coral sclerochronological records as environmental/ ecological recorders in MCEs.

\subsection{Methods}

Porites lutea from water depths of $4 \mathrm{~m}$ and P. lobata from $40 \mathrm{~m}$ off Sesoko Island were collected in 20 August 2014, and $P$. lutea at $40 \mathrm{~m}$ depth off Ie Island, Okinawa, Japan, was collected on 26 January 2013. Two P. lutea colonies were also collected at water depths of 5 and $50 \mathrm{~m}$ from the Gulf of Eilat, Red Sea, Israel, on 29 October 2013 and 1 May 2015, respectively (Fig. 36.1).

\subsubsection{Study Sites}

Sesoko Island is located to the northwest of Okinawa $\left(26^{\circ} 38^{\prime}\right.$ N, $127^{\circ} 51^{\prime}$ E; Fig. 36.1). Seasonal characteristics of seawater temperatures and light intensity both at the surface and upper mesophotic depths $(40 \mathrm{~m})$ were collected from April 2014 to April 2017 (Prasetia et al. 2017). Mean annual water temperature at the surface (1-2 m) around Sesoko Island was $24.9{ }^{\circ} \mathrm{C}$, ranging from $20.6{ }^{\circ} \mathrm{C}$ (February) to $29.2{ }^{\circ} \mathrm{C}$
(August). The seawater temperature at $40 \mathrm{~m}$ depth averaged $24.3^{\circ} \mathrm{C}$, ranging from $21.2^{\circ} \mathrm{C}$ (February) to $27.7^{\circ} \mathrm{C}$ (August; Fig. 36.1). The seasonal amplitudes of seawater temperatures were $8.6{ }^{\circ} \mathrm{C}$ and $6.4{ }^{\circ} \mathrm{C}$ at the surface and $40 \mathrm{~m}$ depth, respectively (Fig. 36.1). Mean annual light intensity at $40 \mathrm{~m}$ depth was $7.7 \%$ of the light intensity at the surface in cloudy conditions and $9.7 \%$ in sunny conditions (Prasetia et al. 2017, see also Sinniger et al. 2019).

The Gulf of Eilat is located in the northern part of the Red Sea $\left(29^{\circ} 33^{\prime} \mathrm{N}, 34^{\circ} 57^{\prime}\right.$ E; Fig. 36.1). The Israel National Monitoring Program (INMP) at the Gulf of Eilat has measured in situ seawater temperature and salinity at different depths, ranging from $700 \mathrm{~m}$ to the surface, since 2004 . From May 2004 to December 2016, annual seawater temperature in shallow water averaged $24.1{ }^{\circ} \mathrm{C}$, ranging from $21.6{ }^{\circ} \mathrm{C}$ (February) to $27.2^{\circ} \mathrm{C}$ (August). MCEs in the Gulf of Eilat occur from 35 to $>150 \mathrm{~m}$ in depth (Loya and Slobodkin 1971; Eyal et al. 2019). The annual seawater temperature at $50 \mathrm{~m}$ depth averaged $23.6^{\circ} \mathrm{C}$, ranging from $21.4^{\circ} \mathrm{C}$ (March) to $25.8{ }^{\circ} \mathrm{C}$ (August), during the same period (Eyal et al. 2019). The seasonal amplitudes of seawater temperatures in the Gulf of Eilat were $5.6{ }^{\circ} \mathrm{C}$ and $4.4^{\circ} \mathrm{C}$ in shallow waters and MCEs, respectively (Fig. 36.1). Light intensity at $36 \mathrm{~m}$ depth was $5.5 \%$ of the light intensity measured at the surface at the Gulf of Eilat (Eyal et al. 2016). Salinity in the Gulf of Eilat is high (> 40.5 PSU) at shallow and mesophotic depths.

\subsubsection{X-Radiography and Skeletal Parameters}

Porites colonies were cut into 5-mm-thick slabs along the maximum growth axis of each colony for $\mathrm{x}$-ray imaging. X-ray images were collected using a NAOMI (RF Co. Ltd., Japan) direct digital radiography CCD imaging sensor at Hokkaido University under exposure conditions of $50 \mathrm{kV}$, $1 \mathrm{~mA}$, and an $8 \mathrm{~s}$ exposure time (Fig. 36.2). Extension rates along the maximum growth axis were estimated using the distance between pairs of high skeletal density maxima identified in the positive x-rays (Fig. 36.2). During the positive $\mathrm{x}$-ray photography, density standardization samples prepared with Tridacna shells were photographed simultaneously to estimate skeletal densities from the grayscale value on the $\mathrm{x}$-ray images. Skeletal density, linear extension, and annual calcification rates of each coral colony were calculated from the grayscale x-ray images following Sowa et al. (2014). Calcification rates were calculated following equation:

Calcification rates $\left(\mathrm{g} \mathrm{cm}^{-2}\right.$ year $\left.^{-1}\right)=$ Skeletal density $\left(\mathrm{g} \mathrm{cm}^{-3}\right) *$ Extension rates $\left(\mathrm{cm} \mathrm{year}^{-1}\right)$ 

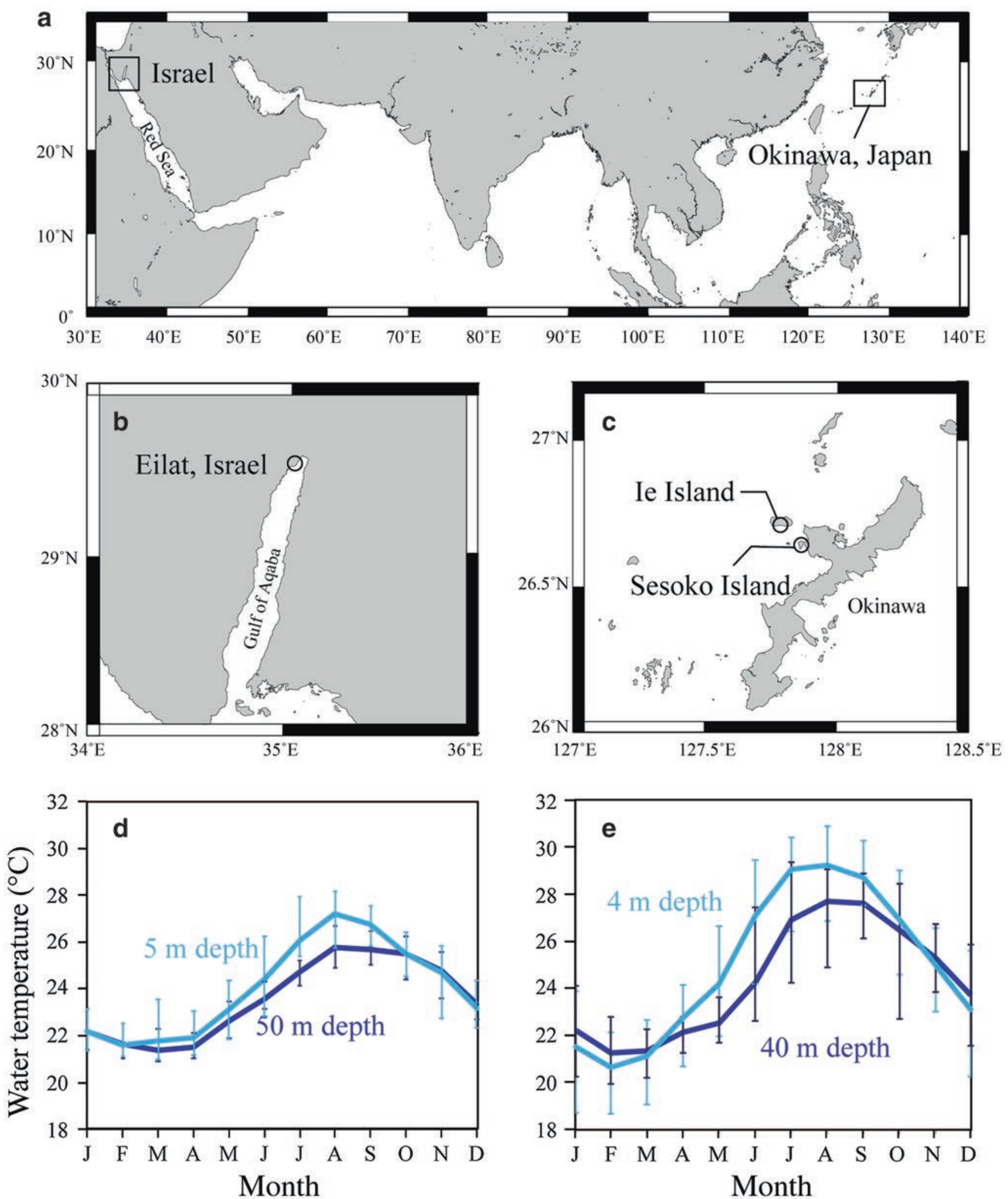

Fig. 36.1 Location of sampling sites in Gulf of Eilat, Red Sea, Israel (a, b), and Sesoko and Ie Islands, Okinawa, Japan (a, c). Also shown are the seasonal characteristics of water temperature at the depths where the Porites samples were collected for this study. The seasonal characteristics of the water temperature at each site were calculated from in situ water temperature observations during the periods from May 2004 to November 2013 for the Gulf of Eilat (d) and from April 2014 to 2017 for Sesoko Island (e) 


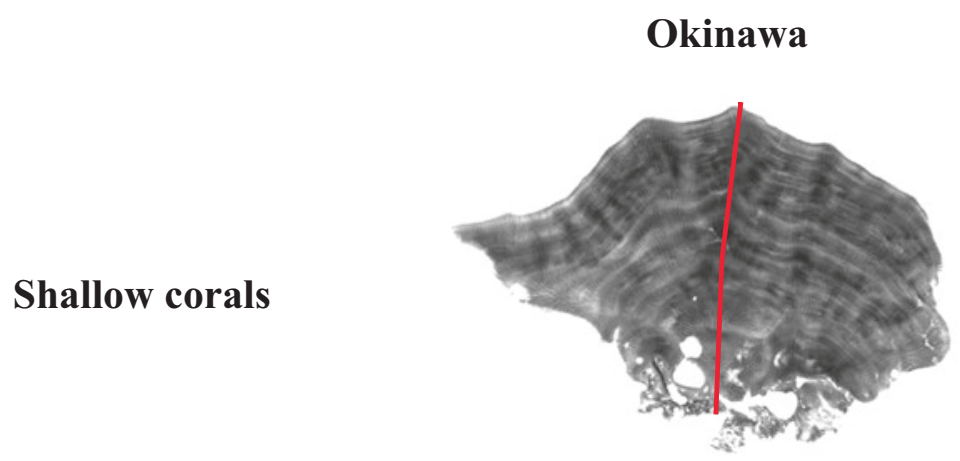

Sesoko 4 m depth

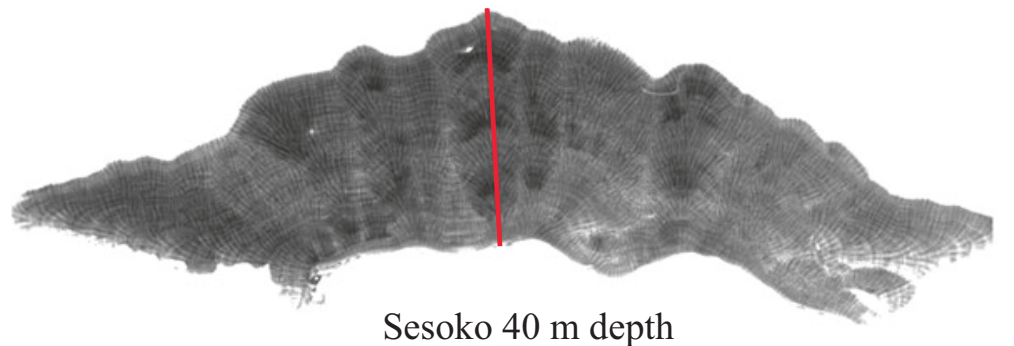

\section{Mesophotic corals}

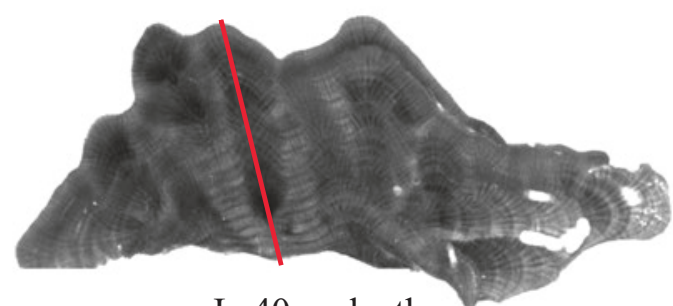

Ie $40 \mathrm{~m}$ depth

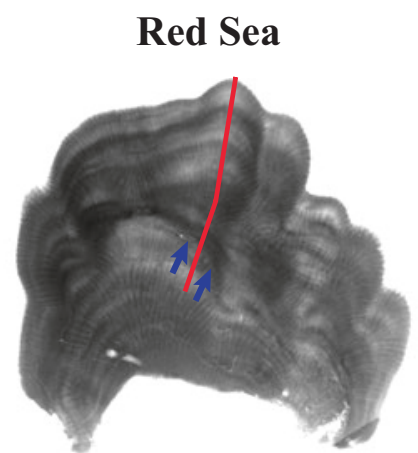

Eilat $5 \mathrm{~m}$ depth

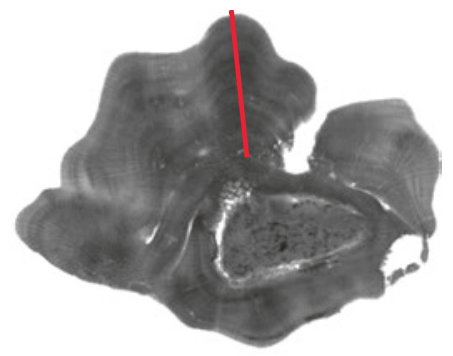

Eilat $50 \mathrm{~m}$ depth

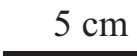

Fig. 36.2 Positive prints of x-rays of Porites corals. Okinawa corals were collected from shallow (4 m) and mesophotic (40 m) depths at Sesoko and Ie Islands. Corals in the Gulf of Eilat were collected from 5 to $50 \mathrm{~m}$ depth. Red lines show the tracks for skeletal growth and isotope analysis. The blue allows indicate the growth disturbance

following Lough and Barnes (2000). Height $(\mathrm{H})$ and width (W) of coral slabs were measured along axes of maximum distances.

\subsubsection{Subsampling for Isotopic Analysis}

We determined the maximum growth axis of each coral slice from positive images of the $\mathrm{x}$-rays to identify sampling tracks (Fig. 36.2). The sampling tracks were cut, and their edges formed into a ledge shape, $2.0 \mathrm{~mm}$ thick and $2.0 \mathrm{~mm}$ wide, using a micro drill. After creating the ledges, the coral slice was ultrasonically cleaned with tap water to remove the powder generated while creating the ledge. Ultrasonic washing with distilled water was carried out twice for 5 min each, after which the slab was dried in an oven at $40{ }^{\circ} \mathrm{C}$ for $24 \mathrm{~h}$. Next, skeletal powder samples were obtained by a precise sampling method using a micro drill (1.8 $\mathrm{mm}$ diameter) and a precision control stage at Hokkaido University. Subsampling intervals were determined depending on the extension rates of each coral colony to obtain $>12$ data points from each annual band, assumed as a couple of high skeletal density bands. Powder samples were collected at $0.4 \mathrm{~mm}(14 \pm 4$ samples/year) and $0.25 \mathrm{~mm}$ (36 \pm 11 samples/year) intervals for shallow reef corals from Sesoko Island and the Gulf of Eilat, respectively, and $0.125 \mathrm{~mm}$ ( $22 \pm 8$ samples/year), $0.2 \mathrm{~mm}(15 \pm 6$ samples/year), and $0.25 \mathrm{~mm}(19 \pm 4$ samples/year) intervals for mesophotic corals from Sesoko Island, Ie Island, and the Gulf of Eilat, respectively.

\subsubsection{Oxygen and Carbon Isotopic Analysis}

Oxygen and carbon isotopes $\left(\delta^{18} \mathrm{O}\right.$ and $\left.\delta^{13} \mathrm{C}\right)$ in all Porites coral specimens were analyzed at Hokkaido University. Corals from $40 \mathrm{~m}$ depth in Ie Island and from $50 \mathrm{~m}$ in the Gulf of Eilat were analyzed by Finnigan MAT 251 isotope ratio mass spectrometry connected with Finnigan Kiel II car- 
bonate devices, which required $100 \mu \mathrm{g}( \pm 10 \mu \mathrm{g})$ of powder per sample. Corals from 4 to $40 \mathrm{~m}$ depth at Sesoko Island and at $5 \mathrm{~m}$ depth in the Gulf of Eilat were analyzed using a Thermo Scientific MAT 253 isotope ratio mass spectrometry connected with Thermo Scientific Kiel IV carbonate devices and required $30 \mu \mathrm{g}( \pm 10 \mu \mathrm{g})$ of powder per sample. Coral carbonate powder was reacted with $100 \% \mathrm{H}_{3} \mathrm{PO}_{4}$ at $70{ }^{\circ} \mathrm{C}$, and the $\mathrm{CO}_{2}$ gas produced purified in the carbonate device before being introduced to the mass spectrometer. Measurement errors of the NBS-19 analysis were within $0.08 \%$ o for $\delta^{18} \mathrm{O}_{\mathrm{VPDB}}$ and $0.05 \%$ of $\delta^{13} \mathrm{C}_{\mathrm{VPDB}}$ with both IRMS (MAT251 and MAT253).

An age model for the isotopic records was established by identifying areas of high density corresponding with annual low $\delta^{18} \mathrm{O}$ in mesophotic corals from Sesoko Island and high density with high $\delta^{18} \mathrm{O}$ in other specimens. Seasonal minimal and maximal $\delta^{18} \mathrm{O}_{\mathrm{VPDB}}$ were selected as time control points and tied to seasonal maximal and minimal seawater temperature records, respectively. Daily resolution AVHRR SST data at $26.375^{\circ} \mathrm{N}, 127.625^{\circ} \mathrm{E}$ (NCDC 2018) were used to establish the age model of coral isotopic records on shallow reefs in Sesoko Island. In situ seawater temperature at 5 and $40 \mathrm{~m}$ depth in Sesoko Island revealed congruence of seasonal maximum and minimum seawater temperatures (August and February) on both shallow and mesophotic reefs (Fig. 36.1). The age model of isotopic records in mesophotic corals from Okinawa was determined in the same way. To establish age model for coral specimens from the Gulf of Eilat, we used in situ monthly seawater temperature at 5 and $40 \mathrm{~m}$ depth from the Gulf of Eilat (INMP 2004-2016). The time series of coral isotopic records were interpolated to monthly resolution with 12 samples per year using AnalySeries software 2.0.8 (Paillard et al. 1996). Annual extension rates for each colony were estimated based on the age model established from seasonal cycle of $\delta^{18} \mathrm{O}$.

\subsection{Results}

\subsubsection{Shallow Corals}

We found significantly higher annual extension rates $(0.60$ $\left.0.86 \mathrm{~cm} \mathrm{year}^{-1}\right)$ and calcification rates $\left(0.86-0.93 \mathrm{~g} \mathrm{~cm}^{-2}\right.$ year $^{-1}$ ) in shallow corals than those in mesophotic corals from Sesoko Island and Gulf of Eilat (annual extension rate, $0.26-0.47 \mathrm{~cm}$ year $^{-1}$; calcification rates, $0.36-0.53 \mathrm{~g} \mathrm{~cm}^{-2}$ year $\left.^{-1}\right)$. However, we found no difference in skeletal density (Table 36.2). $\delta^{18} \mathrm{O}$ in the shallow-water corals from Sesoko Island showed a distinct seasonal cycle, and averaged -4.56 $\pm 0.60 \%$, ranging from $-5.60 \%$ to $-3.43 \%$ o. $\delta^{18} \mathrm{O}$ on the shallow-water reef in the Gulf of Eilat averaged $-3.05 \pm$ $0.35 \%$, ranging from $-3.05 \%$ o to $-2.15 \%$. The average seasonal amplitude of coral $\delta^{18} \mathrm{O}$ was $1.55 \%$ and $0.75 \%$ for the shallow reefs at Sesoko Island and the Gulf of Eilat, respectively (Fig. 36.3; Table 36.3). In the x-ray of corals from the Gulf of Eilat (Fig. 36.2), we observed growth disturbance that may have influenced the anomalously high $\delta^{18} \mathrm{O}$ value relative to SST in winter of 2011 (Fig. 36.3). According to INMP records during 2005-2014, the seasonal variation of salinity in the Gulf of Eilat was between \pm 0.13 at the surface $(0 \mathrm{~m})$ and \pm 0.12 at $40 \mathrm{~m}$ depth, corresponding to seawater $\delta^{18} \mathrm{O}$ values of \pm 0.036 and \pm 0.033 , respectively $\left(\delta^{18} \mathrm{O}_{\mathrm{sw}}=0.281 *\right.$ Salinity -9.14 ; Al-Rousan et al. 2003). Consequently, seasonal variation of seawater $\delta^{18} \mathrm{O}$ could be disregarded as a source in the seasonal variation in $\delta^{18} \mathrm{O}$ in the corals, at least in the Gulf of Eilat. Therefore, assuming that temperature was the primary control of coral $\delta^{18} \mathrm{O}$, the relationship between coral $\delta^{18} \mathrm{O}$ in the shallow depths and SST in monthly resolution at each site were:

$$
\begin{aligned}
& \text { Sesoko Island : } \\
& \delta^{18} \mathrm{O}_{\text {coral }}=-0.20 \pm 0.01 \times \mathrm{SST}-0.64 \pm 0.37(\mathrm{R}=-0.95, \mathrm{n}=26)
\end{aligned}
$$

Gulf of Eilat :

$\delta^{18} \mathrm{O}_{\text {coral }}=-0.16 \pm 0.01 \times \mathrm{SST}+0.82 \pm 0.25(\mathrm{R}=-0.98, \mathrm{n}=13)$

The temperature dependence in the seasonality of $\delta^{18} \mathrm{O}$ on shallow reefs in both Sesoko Island and Gulf of Eilat is consistent with observations of corals in other tropical and subtropical regions and also with estimates based on abiotic aragonite ( -0.16 to -0.23 ; see Fig. 36.4$)$. To evaluate control of $\delta^{18} \mathrm{O}_{\text {coral }}$ in mesophotic corals, we compared $\delta^{18} \mathrm{O}_{\text {coral }}$ with expected $\delta^{18} \mathrm{O}$ from water temperature. Expected $\delta^{18} \mathrm{O}$ from water temperature in Sesoko Island and Gulf of Eilat were estimated to convert from water temperature on shallow and mesophotic depths in each site of Sesoko Island and Gulf of Eilat to $\delta^{18} \mathrm{O}$ using regression equation of $\delta^{18} \mathrm{O}_{\text {coral }}$ vs. water temperature on shallow depths in each site (36.1 and 36.2 ). $\delta^{13} \mathrm{C}$ in the shallow reef averaged $2.91 \pm 0.91 \%$ o (range $-4.78 \%$ o to $-1.02 \%$ ) at Sesoko Island and $-2.90 \pm 0.54 \%$ o (range $-4.36 \%$ o to $-1.69 \%$ ) in the Gulf of Eilat. The average seasonal amplitudes of the $\delta^{13} \mathrm{C}$ were $1.72 \%$ and $0.75 \%$ or the shallow reefs at Sesoko Island and the Gulf of Eilat, respectively (Fig. 36.3; Table 36.3).

\subsubsection{Mesophotic Corals}

The morphological characteristics of the Porites colonies varied between shallow and mesophotic sites, with mesophotic coral colonies exhibiting more flattened forms $(\mathrm{H}, 7.6 \mathrm{~cm}$, and $\mathrm{W}, 32.4 \mathrm{~cm}$, at Sesoko Island and $\mathrm{H}, 6.4 \mathrm{~cm}$, and $\mathrm{W}$, $17.9 \mathrm{~cm}$, at Ie Island) and massive forms on shallow reefs at Sesoko Island (H, $9.6 \mathrm{~cm}$; W, $14.5 \mathrm{~cm}$ ) (Fig. 36.2; Table 36.2). Average annual linear extension rates in MCEs were $0.26 \pm$ $0.11 \mathrm{~cm}$ year $^{-1}(1988-2014)$ at Sesoko Island, $0.28 \pm 0.11 \mathrm{~cm}$ year $^{-1}(1991-2013)$ at Ie Island, and $0.47 \pm 0.12 \mathrm{~cm} \mathrm{year}^{-1}$ 


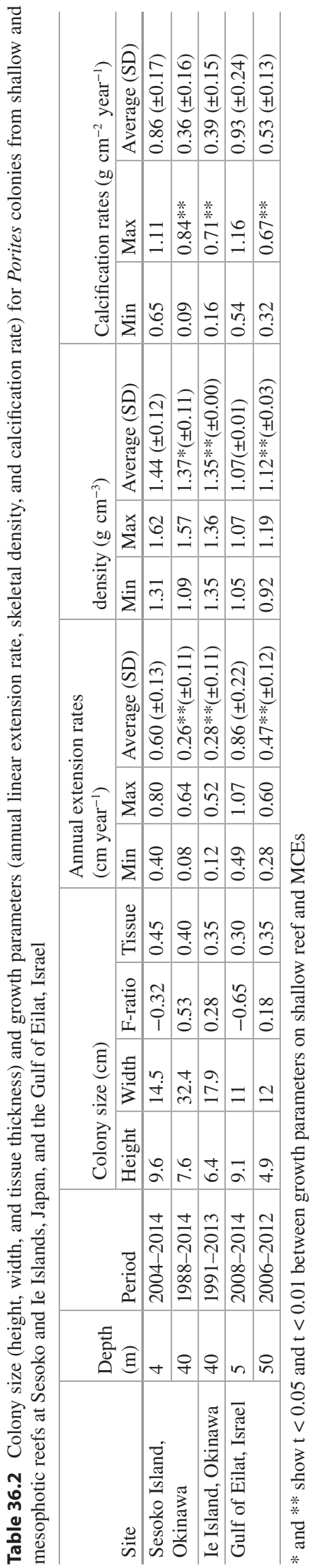




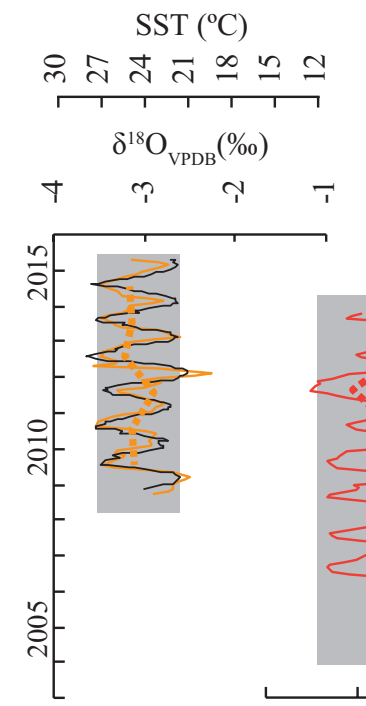

$\operatorname{SST}\left({ }^{\circ} \mathrm{C}\right)$

웜ํำ

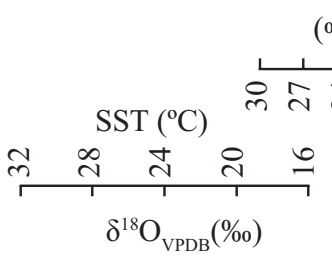

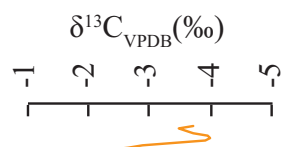

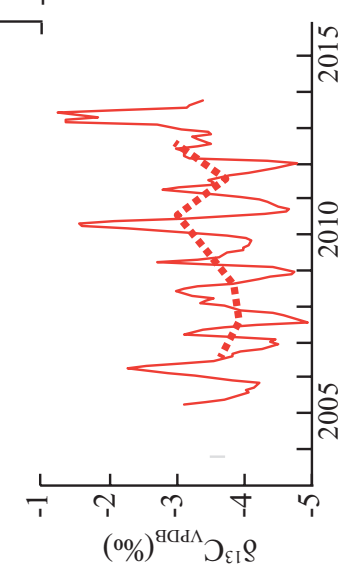

$\%)^{\mathrm{gad} \Lambda} \mathrm{O}_{81} \mathrm{\rho}$

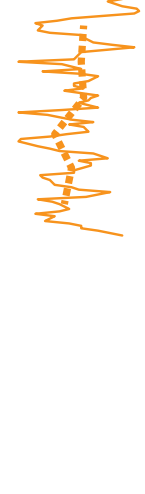

(1)

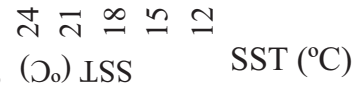
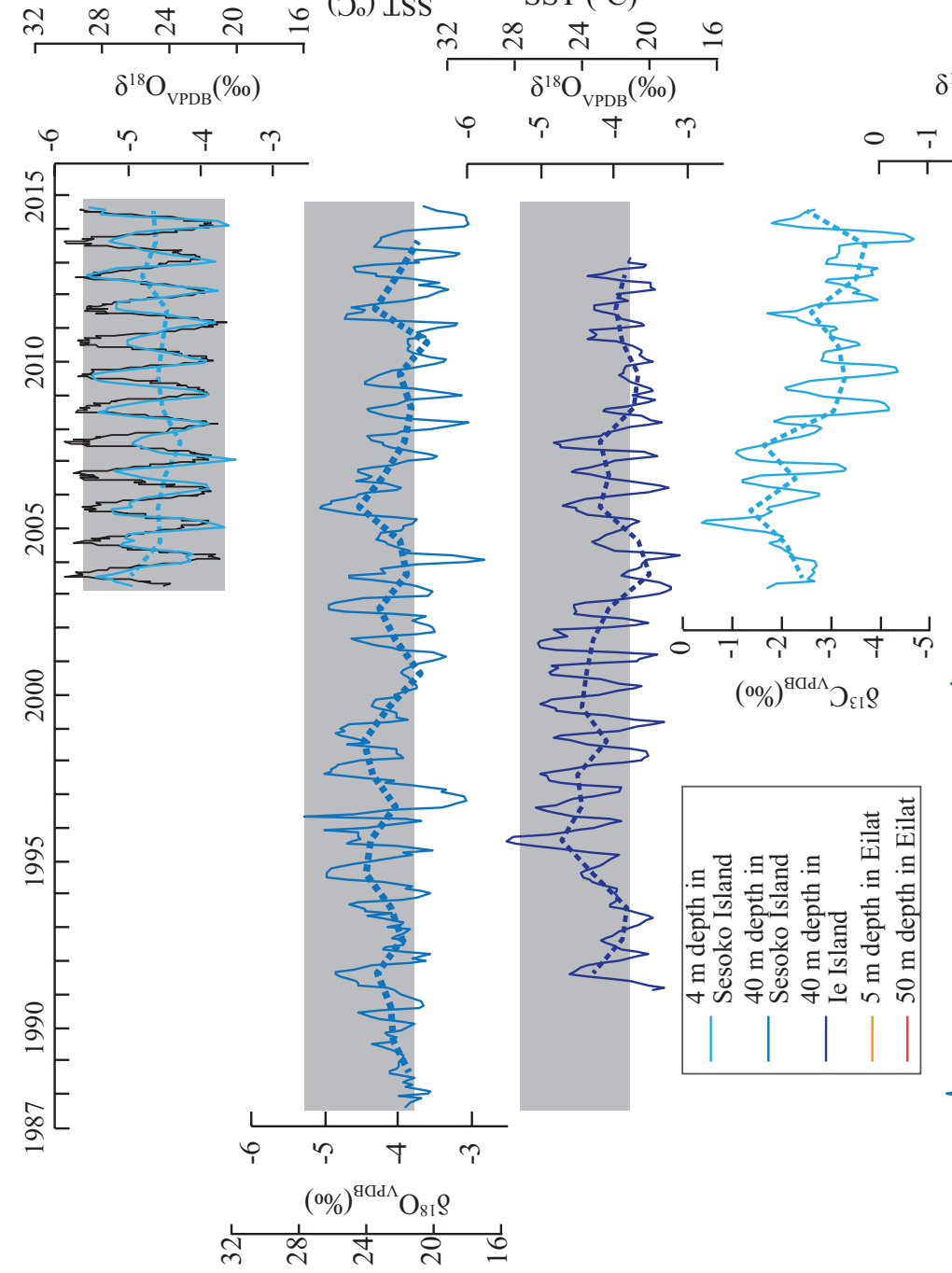

(गo) LSS

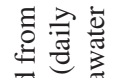

ज

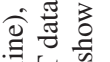

0

일

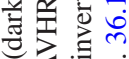

要这

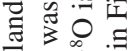

궁

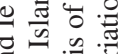

产高

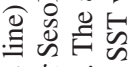

它 $\dot{0}$ 글

氙穴吾

ज्ञ

ปั

竞言是

要范

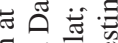

흘.

क्ष

छิ

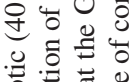

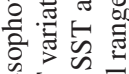

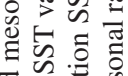

卷

Qิ)

클 줄

总解言

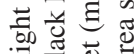

घ․

过苛焉

青获

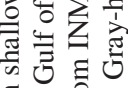

웛

品

윰

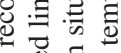

․․

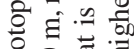

象言

잉. 造

응

o

政

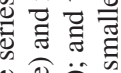

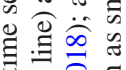

然

츰유.

$\sum \dot{E} \mathrm{z}$

m.

m

棺额 
Table 36.3 Oxygen and carbon isotopes in Porites colonies from shallow and mesophotic reefs from Okinawa (Sesoko and Ie Islands), Japan, and the Gulf of Eilat, Israel

\begin{tabular}{|c|c|c|c|c|c|c|c|c|c|c|}
\hline \multirow[b]{2}{*}{ Site } & \multirow[b]{2}{*}{ Depth (m) } & \multirow[b]{2}{*}{ Period } & \multicolumn{4}{|l|}{$\delta^{18} \mathrm{O}(\% \circ \mathrm{VPDB})$} & \multicolumn{4}{|l|}{$\delta^{13} \mathrm{C}(\% \circ \mathrm{VPDB})$} \\
\hline & & & Average (SD) & Max & Min & $\begin{array}{l}\text { Seasonal } \\
\text { amplitude }\end{array}$ & Average (SD) & Max & Min & $\begin{array}{l}\text { Seasonal } \\
\text { amplitude }\end{array}$ \\
\hline \multirow{2}{*}{$\begin{array}{l}\text { Sesoko } \\
\text { Island, } \\
\text { Okinawa }\end{array}$} & 4 & 2002-2014 & $-4.56 \pm 0.60$ & -3.43 & -5.60 & 1.55 & $-2.91 \pm 0.91$ & -1.02 & -4.78 & 1.72 \\
\hline & 40 & 1987-2014 & $-4.10 * * \pm 0.52$ & -2.73 & -5.44 & 1.39 & $-3.05 * * \pm 0.78$ & -1.19 & -4.85 & 1.74 \\
\hline $\begin{array}{l}\text { Ie Island, } \\
\text { Okinawa }\end{array}$ & 40 & 1991-2012 & $-4.11^{*} \pm 0.54$ & -3.00 & -5.48 & $1.20 * *$ & $-2.75 \pm 0.61$ & -1.01 & -4.30 & $1.40^{*}$ \\
\hline \multirow{2}{*}{$\begin{array}{l}\text { Gulf of } \\
\text { Eilat, Israel }\end{array}$} & 5 & $2008-2015$ & $-3.05 \pm 0.35$ & -2.15 & -3.05 & 0.87 & $-2.90 \pm 0.54$ & -1.69 & -4.36 & 1.38 \\
\hline & 50 & $2005-2013$ & $-2.67 * * \pm 0.53$ & -1.35 & -3.54 & $1.36^{* *}$ & $-3.41 * * \pm 0.92$ & -0.91 & -5.12 & 2.35 \\
\hline
\end{tabular}

$*$ and $* *$ show $\mathrm{t}<0.05$ and $\mathrm{t}<0.01$ between isotopic values in Porites on shallow reef and MCEs

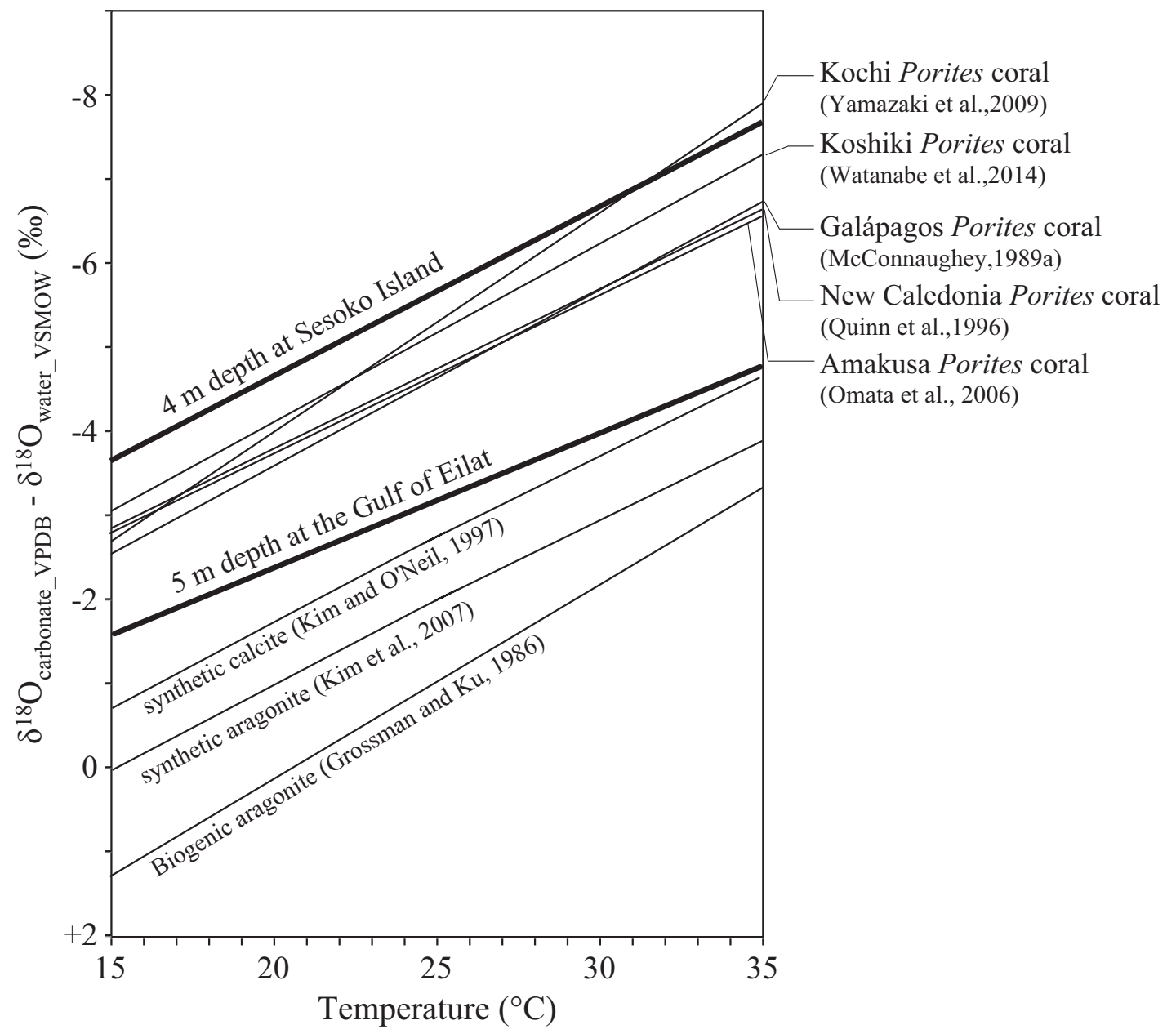

Fig. 36.4 Temperature dependencies of oxygen isotopes in carbonates from shallow corals at Sesoko Island and the Gulf of Eilat, compared with previous studies (Japanese high latitude corals from Kochi: Yamazaki et al. (2009), Koshiki: Watanabe et al. (2014), and Amakusa: Omata et al. (2006); tropical corals from Galapagos: McConnaughey (1989a) and New Caledonia: Quinn et al. (1996); inorganic synthesis of aragonite: Kim et al. (2007) and calcite: Kim and O’Neil (1997); and average of biogenic carbonates: Grossman and Ku (1986)) 
(2006-2012) at the Gulf of Eilat. Average annual skeletal density in MCEs was $1.37 \pm 0.12 \mathrm{~g} \mathrm{~cm}^{-3}(1988-2014)$ at Sesoko Island, $1.35 \pm 0.00 \mathrm{~g} \mathrm{~cm}^{-3}$ (1991-2013) at Ie island, and $1.12 \pm 0.03 \mathrm{~g} \mathrm{~cm}^{-3}(2006-2012)$ at the Gulf of Eilat. Average coral annual calcification rates in MCEs were $0.36 \pm$ $0.15 \mathrm{~g} \mathrm{~cm}^{-2}$ year $^{-1}(1988-2014)$ at Sesoko Island, $0.39 \pm$ $0.15 \mathrm{~cm}^{-2}$ year $^{-1}(1991-2013)$ at Ie Island, and $0.53 \pm 0.13 \mathrm{~cm}^{-2}$ year $^{-1}$ (2006-2012) at the Gulf of Eilat (Table 36.2). Although both linear extension and calcification rates were much lower at mesophotic depths than in adjacent shallows $(\mathrm{t}<0.01)$, skeletal densities in mesophotic corals were similar to shallow-water corals at each site $(\mathrm{t}>0.01)$.

$\delta^{18} \mathrm{O}$ in the mesophotic corals at Sesoko Island averaged $-4.10 \pm 0.52 \%$ o (range -5.44 to $-2.73 \%$ o), while the amplitude of seasonal cycles tended to decrease through time from 1988 to 2014 (Fig. 36.3). $\delta^{18} \mathrm{O}$ in mesophotic corals averaged $-4.11 \pm 0.54 \%$ o (range -5.48 to $-3.00 \%$ ) at Ie Island and $-2.67 \pm 0.53 \%$ o (range -3.54 to $-1.35 \%$ ) in the Gulf of Eilat. The average seasonal range of $\delta^{18} \mathrm{O}$ was $1.33 \%$, $0.68 \%$, and $1.20 \%$ for the mesophotic corals at Sesoko Island, Ie Island, and the Gulf of Eilat, respectively (Table 36.3).

$\delta^{13} \mathrm{C}$ in the mesophotic corals at Sesoko Island averaged $-3.05 \pm 0.78 \%$ o (range -4.85 to $-1.19 \%$ ),$-2.75 \pm$ $0.61 \%$ (range -4.30 to $-1.01 \%$ ) at Ie Island, and -3.41 $\pm 0.92 \%$ (range $-5.12 \%$ and $-0.91 \%$ ) in the Gulf of Eilat. The average seasonal range of $\delta^{13} \mathrm{C}$ was $1.69 \%$, $1.15 \%$, and $1.65 \%$ for the mesophotic corals at Sesoko Island, Ie Island, and the Gulf of Eilat, respectively (Table 36.3).

\subsection{Discussion}

\subsubsection{Coral Growth and Morphological Characteristics in MCEs}

Flattening colony morphology to increase surface area for light capture is a widespread response to increasing depth across a wide range of coral taxa (Fricke and Schuhmacher 1983; Einbinder et al. 2009; Nir et al. 2011), including for Porites colonies transplanted from shallow to deep water in the Gulf of Eilat (Rosenfeld et al. 2003). Lough (2008) demonstrated that the averages of annual linear extension rates, calcification rates, and skeletal densities in corals on shallow reefs were mostly governed by average water temperature. Therefore, corals at mesophotic depths exposed to lower temperatures would be expected to grow more slowly than shallower counterparts. However, coral growth rates may also be influenced by other factors such as light irradiancethe key energetic resource for reef corals. Figure 36.5 shows the comparison between the values of coral growth parameters and annual averages of water temperature in each site of this study, compared to relationships for other shallow reefs in the Indo-Pacific (Lough 2008). In Okinawa, extension rates and calcification rates were much lower at mesophotic depths than expected based on seawater temperature, although there was no effect on skeletal density (Fig. 36.5). In the Gulf of Eilat, skeletal densities in both shallow and mesophotic corals were much smaller than expected from seawater temperature, even though linear extension and calcification rates were consistent with predictions based on seawater temperature (Fig. 36.5).

The variability in coral growth characteristics among habitats and geographic regions suggests that massive Porites may employ different strategies for building their carbonate skeletons based on their environment. While skeletal density was similar for both shallow and mesophotic corals, annual calcification rates were much lower at mesophotic depths ( $\mathrm{t}<0.01$ at both Okinawa and the Gulf of Eilat: Table 36.2), suggesting a limited ability to produce carbonate. The morphological characteristics and small calcification rates of mesophotic corals reported in this study could be influenced by low-light levels, since the temperature differences between shallow and mesophotic reefs are relatively small (Fig. 36.1), but light irradiance at mesophotic depths is only $10 \%$ of that in the shallows (Eyal et al. 2016; Prasetia et al. 2017). In addition, corals in Okinawa are exposed to typhoon disturbances, which sometimes overturn large ( $>1 \mathrm{~m}$ diameter) massive Porites (Hongo et al. 2012), but such events would never occur in an arid climate such as Gulf of Eilat. This variability in hydrodynamics between locations could also influence coral growth and morphology.

\subsubsection{Comparison of Isotopic Signatures Between Shallow and Mesophotic Corals}

Coral isotopic records from all three mesophotic sites (Sesoko Island, Ie Island, and the Gulf of Eilat) showed distinct seasonal cycles, despite lower extension rates than shallow corals (Fig. 36.5). In particular, seasonal variation in skeletal $\delta^{18} \mathrm{O}$ was evident in mesophotic corals at all the three sites. High and low skeletal density couplets in positive $\mathrm{X}$-ray images corresponded with seasonal cycles of $\delta^{18} \mathrm{O}$, and the high skeletal density bands mostly corresponded to seasonally high $\delta^{18} \mathrm{O}$ values in winter. The occurrence of high skeletal density bands in mesophotic corals during winter reported here is consistent with previous reports of Porites corals in high latitudes (the Gulf of Eilat: Klein et al. 1992; Northwest Pacific Ocean: Watanabe et al. 2014; Yamazaki et al. 2016). The similarity in coral $\delta^{18} \mathrm{O}$ signals in both shallow and mesophotic corals, combined with confirmed temperature dependence of coral $\delta^{18} \mathrm{O}$ on shallow reefs, suggests that the primary factor controlling coral $\delta^{18} \mathrm{O}$ is seasonality in seawater temperature. 

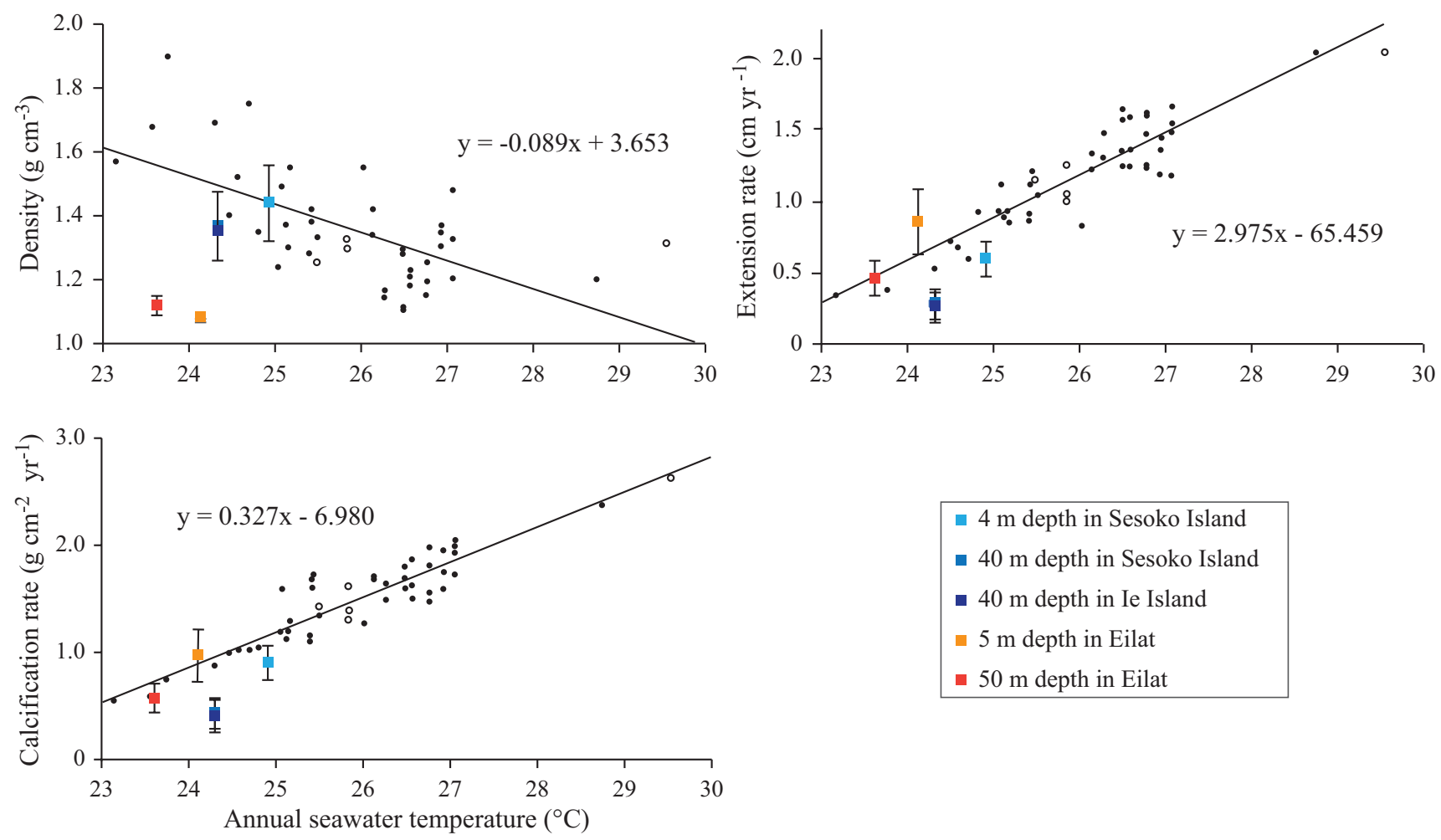

$$
\begin{aligned}
& 4 \mathrm{~m} \text { depth in Sesoko Island } \\
& \text { - } 40 \mathrm{~m} \text { depth in Sesoko Island } \\
& \text { - } 40 \mathrm{~m} \text { depth in Ie Island } \\
& \text { - } 5 \mathrm{~m} \text { depth in Eilat } \\
& \text { - } 50 \mathrm{~m} \text { depth in Eilat }
\end{aligned}
$$

Fig. 36.5 Relationship between seawater temperature and average growth parameters (density, extension rates, and calcification rates) in Porites corals from shallow and mesophotic reefs at Sesoko and Ie Islands, Japan, and the Gulf of Eilat, Israel, compared with the linear relationship reported by Lough (2008)

Seasonal amplitudes in the isotopic signals of mesophotic corals from Sesoko Island were lower than those in shallows, while those in mesophotic from the Gulf of Eilat were higher (Fig. 36.3). Seasonal variability of $\delta^{18} \mathrm{O}$ and $\delta^{13} \mathrm{C}$ was similar or smaller in MCEs than on shallow reefs in Okinawa. In the Gulf of Eilat, however, the seasonal variability of $\delta^{18} \mathrm{O}$ and $\delta^{13} \mathrm{C}$ was larger in the MCEs than in the shallow reefs (Table 36.3; Fig. 36.3), even though the seasonal range of water temperature and irradiance in the MCEs were smaller. For example, the coral $\delta^{18} \mathrm{O}$ in winter in the Gulf of Eilat was higher in mesophotic than shallow corals (Fig. 36.3). Additionally, the seasonal range of temperature estimated from coral $\delta^{18} \mathrm{O}$ at $40 \mathrm{~m}$ depth at Sesoko Island was much higher than the observed in situ temperatures, although temperature records to compare with the isotopic records at mesophotic depths are not available at sufficient temporal scales. We also demonstrated that the range of $\delta^{18} \mathrm{O}$ in mesophotic corals from Okinawa and the Gulf of Eilat was larger than the ranges of $\delta^{18} \mathrm{O}$ estimated from seasonal amplitude of water temperature and temperature dependency of $\delta^{18} \mathrm{O}$ in Eqs. (36.1) and (36.2) (Fig. 36.4). The larger seasonal range in the isotopic records of corals at mesophotic depths, where temperature seasonality and light irradiance are both lower, suggests a strong biological influence on coral isotope geochemistry in mesophotic corals.

\subsubsection{Factors Controlling Coral Isotopic Signals in the MCEs and Their Potential as Environmental/Ecological Indicators}

Environmental factors such as temperature, salinity, and water quality have long been demonstrated as important influences on isotopic variations in shallow corals (Table 36.1). Additional factors including calcification rate (McConnaughey 1989b), coral spawning (Gagan et al. 1996), respiration/photosynthesis in both the coral and symbiotic algae (Swart et al. 1996), the proportion of energy obtained by heterotrophy versus autotrophy (Swart et al. 1998), food sources (Grottoli 2002), and the carbonate ion species in calcified fluid (Adkins et al. 2003; Rollion-Bard et al. 2003) have also been suggested to influence isotopic signatures in corals. McConnaughey (1989b) proposed extension rate-related kinetic effects on coral isotopic records using carbon and oxygen isotopic values from different skeletal portions with different extension rates in a single Pavona coral colony. To examine the kinetic effects on coral isotopic records, we calculated the deviation of annual isotopic values in mesophotic corals from those in shallow corals and compared the deviations with corresponding annual extension rates in each year (Fig. 36.6). Our comparison between the $\delta^{18} \mathrm{O}$ deviations and annual extension rates in all isotopic 

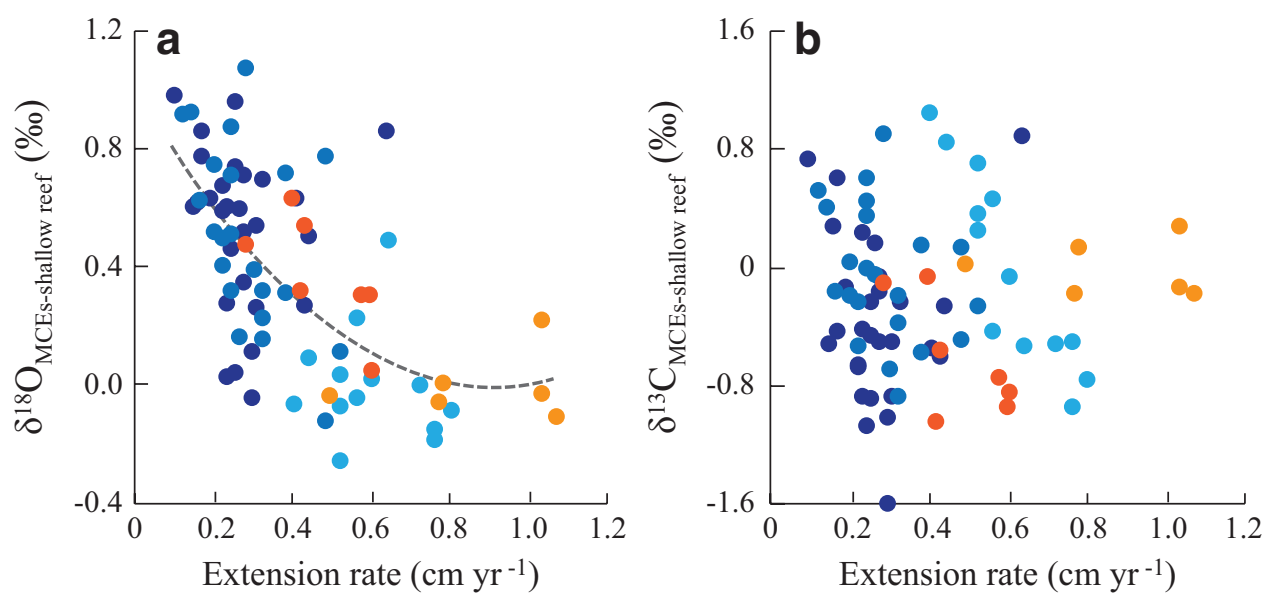

- $4 \mathrm{~m}$ depth in Sesoko Island

- $40 \mathrm{~m}$ depth in Sesoko Island

- $40 \mathrm{~m}$ depth in Ie Island

$5 \mathrm{~m}$ depth in Eilat

- $50 \mathrm{~m}$ depth in Eilat

Fig. 36.6 Comparison of coral linear extension rate with skeletal $\delta^{18} \mathrm{O}(\mathbf{a})$ and $\delta^{13} \mathrm{C}(\mathbf{b})$ anomalies. Fitting line for $\delta^{18} \mathrm{O}(\mathbf{a})$ is $\delta^{18} \mathrm{O}_{\text {anomaly }}=1.24 \times$ $(\text { Ext. rate })^{2}-2.24 \times($ Ext. rate $)+1.00\left(\mathrm{R}^{2}=0.43\right)$

records in the Porites specimens showed a negative relationship (Fig. 36.6a). A similar trend in coral $\delta^{18} \mathrm{O}$ was also reported by McConnaughey (1989b) and Felis et al. (2003), suggesting that extension rates can be a controlling factor for mesophotic coral $\delta^{18} \mathrm{O}$. On the other hand, this extension rate-related influence was not evident for the coral $\delta^{13} \mathrm{C}$ (Fig. 36.6b). The different responses of coral $\delta^{18} \mathrm{O}$ and $\delta^{13} \mathrm{C}$ to extension rate may imply that the controlling factors for extension rate in MCEs were similar for coral $\delta^{18} \mathrm{O}$ (most likely temperature), but different for coral $\delta^{13} \mathrm{C}$. If kinetic effects are one of the dominant controlling factors in coral isotopic signals, both carbon and oxygen isotopes should have been influenced in the same manner with varying extension rates (i.e., more negative at higher extension rates).

Gagan et al. (2012) discussed how "bio-smoothing" within the living coral tissue layer can attenuate geochemical and isotopic signals in corals when the temperature dependency of $\delta^{18} \mathrm{O}$ is less than $0.23 \%{ }^{\circ}{ }^{\circ} \mathrm{C}$ (Eqs. 36.1 and 36.2). The tissue layer on the mesophotic corals from Okinawa was thicker than the average linear extension rates (Table 36.2), in contrast to shallow-water corals from Okinawa and the Gulf of Eilat. Bio-smoothing (Gagan et al. 2012) could potentially explain the isotopic variations in the mesophotic corals from Okinawa, but evaluating its effects would require analysis of $\mathrm{Sr} / \mathrm{Ca}$ ratios. However, seasonal variations of coral isotopes in mesophotic corals are greater than those on shallow reefs even after accounting for bio-smoothing. Therefore, it is necessary to also consider other potentially important effects of the mesophotic environment on coral skeletons to fully interpret their isotopic signatures.

Adkins et al. (2003) explained the non-synchronized vital effects on carbon and oxygen isotope signals observed in deep-sea corals using a conceptual model that proposed a mechanism in which the carbonate ion species shifts with changing $\mathrm{pH}$ in extracellular calcified fluid, thereby affecting coral $\delta^{18} \mathrm{O}$ and growth. This hypothesis is consistent with the large heterogeneity of $\delta^{18} \mathrm{O}$ and $\delta^{11} \mathrm{~B}$ (boron isotope as a proxy for $\mathrm{pH}$ ) observed in the microstructures of Porites skeletons (Rollion-Bard et al. 2003) and might explain the isotopic patterns we observed in MCEs.

$\delta^{13} \mathrm{C}$ in mesophotic corals must be influenced by other biological controls, although the mechanisms of coral $\delta^{13} \mathrm{C}$ production are complicated (Table 36.1). Metabolic fractionation produces the skeletal $\delta^{13} \mathrm{C}$ changes that reflect those in symbiont photosynthesis and host respiration (Swart 1983; Muscatine et al. 1989; McConnaughey 1989a, b; McConnaughey et al. 1997; Gattuso et al. 1999; Grottoli and Wellington 1999). Because a low rate of photosynthesis decreases the $\delta^{13} \mathrm{C}$ values in the internal DIC pool, these values have been used as a proxy for solar irradiance (Cole and Fairbanks 1990; Grottoli and Wellington 1999; Reynaud-Vaganay et al. 2001; Grottoli 2002) and water depth (e.g., Weber et al. 1976; Grottoli and Wellington 1999; Heikoop et al. 2000; Rosenfeld et al. 2003; Dassié et al. 2013). Both annual mean and seasonal range of solar radiation are lower on mesophotic than shallow reefs at Sesoko Island and the Gulf of Eilat (Eyal et al. 2016; Prasetia et al. 2017), thus $\delta^{13} \mathrm{C}$ in mesophotic corals should also show smaller seasonal amplitudes if amounts of $\mathrm{CO}_{2}$ from photosynthesis of the symbiotic algae were the primarily control factor of $\delta^{13} \mathrm{C}$.

The similar or larger seasonal and interannual variability observed in $\delta^{13} \mathrm{C}$ in mesophotic corals suggests that additional factors influence $\delta^{13} \mathrm{C}$. Trophic changes between shal- 
low and mesophotic corals offer one possible explanation. A high level of heterotrophic feeding in corals could decrease $\delta^{13} \mathrm{C}$ in coral skeletons because zooplankton have the lower $\delta^{13} \mathrm{C}$ values $(<-20 \%$ ) than corals (Felis et al. 1998; Grottoli and Wellington 1999; Grottoli 2002; Palardy et al. 2008; Hughes et al. 2010). Heterotrophic pathways of organic carbon related to feeding may be more dominant and flexible on mesophotic than shallow reefs. Nevertheless, the coral isotopic time series of $\delta^{18} \mathrm{O}$ and $\delta^{13} \mathrm{C}$ in mesophotic corals from Okinawa showed a similar seasonal to interannual variability, which implies that isotopic signals in mesophotic corals captured environmental variability (Fig. 36.3). Environmental and physiological monitoring in MCEs (e.g., light intensity and particle flux on a seasonal cycle, photosynthetic rates, and respiration rates) and examination of additional geochemical proxies (Table 36.1) are required to understand the exact mechanisms for coral calcification and their physiological processes.

Future research to better understand the effects of depth on coral geochemistry could be aided by examining Porites corals across smaller intervals of depth and analyzing nitrogen isotopes in the plankton, polyp tissues, and the skeletal organic matter. In addition, aquaria experiments, which simulate light conditions in MCEs, to examine the responses in coral skeletal growth and geochemical composition, could provide greater insight into the response of corals to mesophotic environments. Although the isotopic signals in corals from MCEs recorded interannual variability and distinct seasonal cycles similar to shallow reefs, the isotopic values in MCEs showed large fluctuations and shifted to larger $\delta^{18} \mathrm{O}$ and smaller $\delta^{13} \mathrm{C}$ ratios. The differences in the isotopic signals between shallow and mesophotic corals suggest that coral geochemical records in MCEs are more sensitive to physiological processes such as symbiont photosynthesis, calcification rates, and trophic level than environmental variability. However, our results also show the strong potential of sclerochronological approaches to capture decadal changes in environmental conditions on mesophotic reefs, facilitating a greater understanding of the long-term environmental and ecological characteristics of these poorly known ecosystems.

Acknowledgments We thank M. Hama, H. Kajita, and Y. Sato for sample preparation and T. Irino for assistance and maintenance of mass spectrometry used in this study. This study was supported by the Grantin-Aid for Scientific Research (A) and (B) from Japan Society for the Promotion of Science (No. 25257207 and No. 15H03742) to TW, the Grant-in-Aid for Scientific Research (A) from Japan Society for the Promotion of Science (No. 16H02490) to SH, the European Union's Horizon 2020 research and innovation program under the Marie Skłodowska-Curie GF grant (No. 796025) to GE and the Israel Science Foundation (ISF) Grant (No. 1191/16) and USAID/MERC Grant (No. M32-037) to YL.

\section{References}

Abram NJ, McGregor HV, Tierney JE et al (2016) Early onset of industrial-era warming across the oceans and continents. Nature 536:411-418

Adkins JF, Boyle EA, Curry WB, Lutringer A (2003) Stable isotopes in deep-sea corals and a new mechanism for "vital effects." Geochim Cosmochim Acta 67:1129-1143

Alibert C, McCulloch MT (1997) Corals from the Great Barrier Reef as a proxy for sea surface temperature: calibration of the thermometer and monitoring of ENSO. Paleoceanography 12:345

Al-Rousan S, Al-Moghrabi S, Pätzold J et al (2003) Stable oxygen isotopes in Porites corals monitor weekly temperature variations in the northern Gulf of Aqaba, Red Sea. Coral Reefs 22:346-356

Beck JW, Edwards RL, Ito E et al (1992) Sea-surface temperature from coral skeletal strontium/calcium ratios. Science (New York, NY) 257:644-647

Barnes DJ, Taylor RB (2001) On the nature and causes of luminescent lines and bands in coral skeletons. Coral Reefs 19(3):221-230

Bongaerts P, Ridgway T, Sampayo EM, Hoegh-Guldberg O (2010) Assessing the "Deep Reef Refugia" hypothesis: focus on Caribbean reefs. Coral Reefs 29:1-19

Cheal AJ, MacNeil MA, Emslie MJ, Sweatman H (2017) The threat to coral reefs from more intense cyclones under climate change. Glob Chang Biol 23:1511-1524

Cole JE, Fairbanks RG (1990) The Southern Oscillation recorded in the $\delta^{18} \mathrm{O}$ of corals from Tarawa Atoll. Paleoceanography 5:669-683

Cole JE, Fairbanks RG, Shen GT (1993) Recent variability in the Southern Oscillation: isotopic results from a Tarawa Atoll Coral. Science 260(5115):1790-1793

Corrège T, Delcroix T, Récy J et al (2000) Evidence for stronger El Niño-Southern Oscillation (ENSO) events in a mid-Holocene massive coral. Paleoceanography 15(4):465-470

Corrège T, Gagan MK, Beck JW et al (2004) Interdecadal variation in the extent of South Pacific tropical waters during the Younger Dryas event. Nature 428(6986):927-929

Dassié EP, Lemley GM, Linsley BK (2013) The Suess effect in Fiji coral $\delta \mathrm{C}$ and its potential as a tracer of anthropogenic $\mathrm{CO}$ uptake. Palaeogeogr Palaeoclimatol Palaeoecol 370:30-40

Dodge RE, Brass GW (1984) Skeletal extension, density and calcification of the reef coral, Montastrea annularis: St. Croix, U.S. Virgin Islands. Bull Mar Sci 34:288-307

Dodge RE, Thomson J (1974) The natural radiochemical and growth records in contemporary hermatypic corals from the Atlantic and Caribbean. Earth Planet Sci Lett 23(3):313-322

Dunbar RB, Wellington GM (1981) Stable isotopes in a branching coral monitor seasonal temperature variation. Nature 293(5832):453-455

Dunbar RB, Wellington GM, Colgan MW, Glynn PW (1994) Eastern Pacific sea surface temperature since 1600 A.D.: the record of climate variability in Galápagos corals. Paleobiology 9(2):291-315

Einbinder S, Mass T, Brokovich E et al (2009) Changes in morphology and diet of the coral Stylophora pistillata along a depth gradient. Mar Ecol Prog Ser 381:167-174

Epstein S, Buchsbaum R, Lowenstam HA et al (1953) Revised carbonate-water isotopic temperature scale. Geol Soc Am Bull 64(11):1315-1326

Eyal G, Eyal-Shaham L, Cohen I et al (2016) Euphyllia paradivisa, a successful mesophotic coral in the northern Gulf of Eilat/Aqaba, Red Sea. Coral Reefs 35(1):91-102

Eyal G, Tamir R, Kramer N, Eyal-Shaham L, Loya Y (2019) The Red Sea: Israel. In: Loya Y, Puglise KA, Bridge TCL (eds) Mesophotic coral ecosystems. Springer, New York, pp 199-214 
Felis T, Pätzold J, Loya Y et al (1998) Vertical water mass mixing and plankton blooms recorded in skeletal stable carbon isotopes of a Red Sea coral. J Geophys Res Oceans 103(C13):30731-30739

Felis T, Pätzold J, Loya Y et al (2000) A coral oxygen isotope record from the northern Red Sea documenting NAO, ENSO and North Pacif connection on Middle East climate variability since 1750 . Paleoceanography 15:679-694

Felis T, Pätzold J, Loya (2003) Mean oxygen-isotope signatures in Porites spp. corals: inter-colony variability and correction for extension-rate effects. Coral Reefs 22(4):328-336

Felis T, Lohmann G, Kuhnert H et al (2004) Increased seasonality in Middle East temperatures during the last interglacial period. Nature 429(6988):164-168

Fricke HW, Schuhmacher H (1983) The depth limits of Red Sea stony corals: an ecophysiological problem (a deep diving survey by submersible). Mar Ecol 4(2):163-194

Gagan MK, Chivas AR, Isdale PJ (1996) Timing coral-based climatic histories using ${ }^{13} \mathrm{C}$ enrichments driven by synchronized spawning. Geology 24(11):1009-1012

Gagan MK, Ayliffe LK, Hopley D et al (1998) Temperature and surfaceocean water balance of the mid-Holocene tropical western Pacific. Science 279(5353):1014-1018

Gagan MK, Ayliffe LK, Beck JW et al (2000) New views of tropical paleoclimates from corals. Quat Sci Rev 19(1):45-64

Gagan MK, Dunbar GB, Suzuki A (2012) The effect of skeletal mass accumulation in Porites on coral $\mathrm{Sr} / \mathrm{Ca}$ and $\delta^{18} \mathrm{O}$ paleothermometry. Paleoceanography 27(1):1-16

Gattuso JP, Allemand D, Frankignoulle M (1999) Photosynthesis and calcification at cellular, organismal and community levels in coral reefs: a review on interactions and control by carbonate chemistry. Am Zool 39:160-183

Glynn PW (1996) Coral reef bleaching: facts, hypotheses and implications. Glob Chang Biol 2:495-509

Grossman EL, Ku TL (1986) Oxygen and carbon isotope fractionation in biogenic aragonite: temperature effects. Chem Geol: Isot Geosci sect 59:59-74

Grottoli AG (2002) Effect of light and brine shrimp on skeletal $\delta^{13} \mathrm{C}$ in the Hawaiian coral Porites compressa: a tank experiment. Geochim Cosmochim Acta 66(11):P1955-P1967

Grottoli AG, Eakin CM (2007) A review of modern coral $\delta^{18} \mathrm{O}$ and $\Delta^{14} \mathrm{C}$ proxy records. Earth Sci Rev 81:67-91

Grottoli AG, Wellington GM (1999) Effect of light and zooplankton on skeletal $\delta^{13} \mathrm{C}$ values in the eastern Pacific corals Pavona clavus and Pavona gigantea. Coral Reefs 18(1):29-41

Grove CA, Nagtegaal R, Zinke J et al (2010) River runoff reconstructions from novel spectral luminescence scanning of massive coral skeletons. Coral Reefs 29(3):579-591

Heikoop JM, Dunn JJ, Risk MJ et al (2000) Separation of kinetic and metabolic isotope effects in carbon-13 records preserved in reef coral skeletons. Geochim Cosmochim Acta 64:975-987

Hongo C, Kawamata H, Goto K (2012) Catastrophic impact of typhoon waves on coral communities in the Ryukyu Islands under global warming. J Geophys Res Biogeosci 117(G2):G02029

Hönisch B, Hemming NG, Grottoli AG et al (2004) Assessing scleractinian corals as recorders for paleo-pH: empirical calibration and vital effects. Geochim Cosmochim Acta 68(18):3675-3685

Hughes AD, Grottoli AG, Pease TK et al (2010) Acquisition and assimilation of carbon in non-bleached and bleached corals. Mar Ecol Prog Ser 420:91-101

Hughes TP, Kerry JT, Alvarez-Noriega M et al (2017) Global warming and recurrent mass bleaching of corals. Nature 543:373-377

Hughes TP, Anderson KD, Connolly SR et al (2018) Spatial and temporal patterns of mass bleaching of corals in the Anthropocene. Science 359(6371):80-83

Huston M (1985) Variation in coral growth rates with depth at Discovery Bay, Jamaica. Coral Reefs 4(1):19-25
Israel National Monitoring Program [INMP] (2004-2016) Israel National Monitoring Program at the Gulf of Eilat, scientific reports and dataset. The Interuniversity Institute for Marine Sciences in Eilat (IUI). http://www.iui-eilat.ac.il/Research/NMPAbout.aspx

Kahng SE, García-Sais JR, Spalding HL et al (2010) Community ecology of mesophotic coral reef ecosystems. Coral Reefs 29(2):255-275

Kim ST, O'Neil JR (1997) Equilibrium and nonequilibrium oxygen isotope effects in synthetic carbonates. Geochim Cosmochim Acta 61(16):3461-3475

Kim ST, O'Neil JR, Hillaire-Marcel C et al (2007) Oxygen isotope fractionation between synthetic aragonite and water: influence of temperature and $\mathrm{Mg}^{2+}$ concentration. Geochim Cosmochim Acta 71:4704-4715

Klein R, Loya Y, Gvirtzman G et al (1990) Seasonal rainfall in the Sinai desert during the late Quaternary inferred from fluorescent bands in fossil corals. Nature 345:145-147

Klein R, Pätzold J, Wefer G et al (1992) Seasonal variations in the stable isotopic composition and skeletal density pattern of the coral Porites lobata (Gulf of Eilat, Red Sea). Mar Biol 112:259-263

Klein R, Pätzold J, Wefer G et al (1993) Depth-related timing of density band formation in Porites spp. corals from the Red Sea inferred from x-ray chronology and stable isotope composition. Mar Ecol Prog Ser 97:99-104

Knutson DW, Buddemeier RW, Smith SV (1972) Coral chronometers: seasonal growth bands in reef corals. Science 177(4045):270-272

LaVigne M, Field MP, Anagnostou E et al (2008) Skeletal P/Ca tracks upwelling in Gulf of Panama coral: evidence for a new seawater phosphate proxy. Geophys Res Lett 35(5):L05604

LaVigne M, Matthews KA, Grottoli AG et al (2010) Coral skeleton P/ Ca proxy for seawater phosphate: multi-colony calibration with a contemporaneous seawater phosphate record. Geochim Cosmochim Acta 74(4):1282-1293

Lea DW, Shen GT, Boyle EA (1989) Coralline barium records temporal variability in equatorial Pacific upwelling. Nature 340:373-376

Lough JM (2007) Tropical river flow and rainfall reconstructions from coral luminescence: Great Barrier Reef, Australia. Paleoceanography 22(2):PA2218

Lough JM (2008) Coral calcification from skeletal records revisited. Mar Ecol Prog Ser 373:257-264

Lough JM (2011) Great Barrier Reef coral luminescence reveals rainfall variability over northeastern Australia since the 17th century. Paleoceanography 26(2):PA2201

Lough JM, Barnes DJ (2000) Environmental controls on growth of the massive coral Porites. J Exp Mar Biol Ecol 245(2):225-243

Lough JM, Cooper TF (2011) Earth-science reviews new insights from coral growth band studies in an era of rapid environmental change. Earth-Sci Rev 108(3-4):170-184

Loya Y, Slobodkin LB (1971) The coral reefs of Eilat (Gulf of Eilat, Red Sea). Symp Zool Soc Lond 28:117-139

Loya Y, Eyal G, Treibitz T et al (2016) Theme section on mesophotic coral ecosystems: advances in knowledge and future perspectives. Coral Reefs 35(1):1-9

Marion GS, Dunbar RB, Mucciarone DA et al (2005) Coral skeletal $\delta^{15} \mathrm{~N}$ reveals isotopic traces of an agricultural revolution. Mar Pollut Bull 50(9):931-944

Marshall JF, McCulloch MT (2002) An assessment of the Sr/Ca ratio in shallow water hermatypic corals as a proxy for sea surface temperature. Geochim Cosmochim Acta 66(18):3263-3280

McConnaughey $\mathrm{T}$ (1989a) ${ }^{13} \mathrm{C}$ and ${ }^{18} \mathrm{O}$ isotopic disequilibrium in biological carbonates: I. Patterns. Geochim Cosmochim Acta 53(1):151-162

McConnaughey $\mathrm{T}(1989 \mathrm{~b}){ }^{13} \mathrm{C}$ and ${ }^{18} \mathrm{O}$ isotopic disequilibrium in biological carbonates: II. In vitro simulation of kinetic isotope effects. Geochim Cosmochim Acta 53(1):163-171

McConnaughey TA, Burdett J, Whelan JF et al (1997) Carbon isotopes in biological carbonates: respiration and photosynthesis. Geochim Cosmochim Acta 61(3):611-622 
McCulloch M, Fallon S, Wyndham T et al (2003) Coral record of increased sediment flux to the inner Great Barrier Reef since European settlement. Nature 421(6924):727-730

Mitsuguchi T, Matsumoto E, Abe O et al (1996) Mg/Ca thermometry in coral skeletons. Science 274(5289):961-963

Montaggioni LF, Le Cornec F, Corrège T et al (2006) Coral barium/calcium record of mid-Holocene upwelling activity in New Caledonia, South-West Pacific. Palaeogeogr Palaeoclimatol Palaeoecol 237(2):436-455

Muscatine L, Porter JW, Kaplan IR (1989) Resource partitioning by reef corals as determined from stable isotope composition. Mar Biol 100(2):185-193

National Climatic Data Center [NCDC] (2018) Daily sea surface temperature dataset at $26.375^{\circ} \mathrm{N}, 127.625^{\circ} \mathrm{E}$. National Oceanic and Atmospheric Administration NCDC OISST (Optimum Interpolation Sea Surface Temperature) version2 AVHRR (Advanced Very High Resolution Radiometer). http://iridl.ldeo.columbia.edu/SOURCES/. NOAA/.NCDC/.OISST/.version2/.AVHRR/.sst/. Accessed $30 \mathrm{Apr}$ 2018

Nir O, Gruber DF, Einbinder S et al (2011) Changes in scleractinian coral Seriatopora hystrix morphology and its endocellular Symbiodinium characteristics along a bathymetric gradient from shallow to mesophotic reef. Coral Reefs 30(4):1089-1100

Nozaki Y, Rye DM, Turekian KK et al (1978) A 200 year record of carbon-13 and carbon-14 variations in a Bermuda coral. Geophys Res Lett 5(10):825-828

Nyberg J (2002) Luminescence intensity in coral skeletons from Mona Island in the Caribbean Sea and its link to precipitation and wind speed. Philos Trans R Soc Lond A Math Phys Eng Sci 360(1793):749-766

Omata T, Suzuki A, Kawahata H et al (2006) Oxygen and carbon stable isotope systematics in Porites coral near its latitudinal limit: the coral response to low-thermal temperature stress. Glob Planet Chang 53:137-146

Paillard D, Labeyrie L, Yiou P (1996) Macintosh Program performs time-series analysis. Eos 77(39):379

Palardy JE, Rodrigues LJ, Grottoli AG (2008) The importance of zooplankton to the daily metabolic carbon requirements of healthy and bleached corals at two depths. J Exp Mar Biol Ecol 367(2):180-188

Prasetia R, Sinniger F, Hashizume K et al (2017) Reproductive biology of the deep brooding coral Seriatopora hystrix: implications for shallow reef recovery. PLoS ONE 12(5):e0117034

Quinn TM, Florida S, Crowley TJ et al (1996) New stable isotope results from a 173-year coral from Espiritu Santo, Vanuatu. Geophys Res Lett 23(23):3413-3416

Reynaud S, Hemming NG, Juillet-Leclerc A et al (2004) Effect of $\mathrm{pCO}_{2}$ and temperature on the boron isotopic composition of the zooxanthellate coral Acropora sp. Coral Reefs 23(4):539-546

Reynaud-Vaganay S, Juillet-Leclerc A, Jaubert J et al (2001) Effect of light on skeletal $\delta^{13} \mathrm{C}$ and $\delta^{18} \mathrm{O}$, and interaction with photosynthesis, respiration and calcification in two zooxanthellate scleractinian corals. Palaeogeogr Palaeoclimatol Palaeoecol 175(1):393-404

Rollion-Bard C, Chaussidon M, France-Lanord C (2003) pH control on oxygen isotopic composition of symbiotic corals. Earth Planet Sci Lett 215(1-2):275-288

Rosenfeld M, Shemesh A, Loya Y (2003) Implication of water depth on stable isotope composition and skeletal and density banding. Coral Reefs 22:337-345

Scoffin TP, Tudhope AW, Brown BE (1989) Fluorescent and skeletal density banding in Porites Lutea from Papua New-Guinea and Indonesia. Coral Reefs 7(4):169-178

Sinniger F, Harii S, Humblet M, Nakamura Y, Ohba H, Prasetia R (2019) Ryukyu Islands, Japan. In: Loya Y, Puglise KA, Bridge TCL (eds) Mesophotic coral ecosystems. Springer, New York, pp 231-247
Smith SV, Buddemeier RW, Redalje RC et al (1979) Strontium-calcium thermometry in coral skeletons. Science 204(4391):404-407

Sowa K, Watanabe T, Kan H et al (2014) Influence of land development on Holocene, Porites coral calcification at Nagura bay, Ishigaki island, Japan. PLoS ONE 9(2):e88790

Stephans CL, Quinn TM, Taylor FW et al (2004) Assessing the reproducibility of coral-based climate records. Geophys Res Lett 31(18):L18210

Swart PK (1983) Carbon and oxygen isotope fractionation in scleractinian corals: a review. Earth Sci Rev 19(1):51-80

Swart PK, Healy G, Dodge RE et al (1996) The stable oxygen and carbon isotopic record of climatic and anthropogenic influence. Palaeogeogr Palaeoclimatol Palaeoecol 123:219-237

Swart PK, White KS, Enfield D et al (1998) Stable oxygen isotopic composition of corals from the Gulf of Guinea as indicators of periods of extreme precipitation conditions in the sub-Sahara. J Geophys Res Oceans 103(C12):27885-27891

Tortolero-Langarica JJA, Rodríguez-Troncoso AP, Carricart JP et al (2016) Skeletal extension, density and calcification rates of massive free-living corals Porites lobata Dana, 1846. J Exp Mar Biol Ecol 478:68-76

Trotter J, Montagna P, MuCulloch M et al (2011) Quantifying the $\mathrm{pH}$ 'vital effect' in the temperate zooxanthellate coral Cladocora caespitosa: validation of the boron seawater $\mathrm{pH}$ proxy. Earth Planet Sci Lett 303(3): 163-173

Tudhope AW, Chilcott CP, MuCulloch MT et al (2001) Variability in the El Niño-Southern Oscillation through a glacial-interglacial cycle. Science 291(5508): 1511-1517

Wang XT, Sigman DM, Cohen AL et al (2015) Isotopic composition of skeleton-bound organic nitrogen in reef-building symbiotic corals: a new method and proxy evaluation at Bermuda. Geochim Cosmochim Acta 148:179-190

Watanabe T, Minagawa M, Oba T et al (2001) Pretreatment of coral aragonite for $\mathrm{Mg}$ and $\mathrm{Sr}$ analysis: implications for coral thermometers. Geochem J 35(4):265-269

Watanabe T, Gagan MK, Corrége T et al (2003) Oxygen isotope systematics in Diploastrea heliopora: new coral archive of tropical paleoclimate. Geochim Cosmochim Acta 67(7):1349-1358

Watanabe T, Kawamura T, Yamazaki A et al (2014) A 106 year monthly coral record reveals that the East Asian summer monsoon modulates winter PDO variability. Geophys Res Lett 41:3609-3614

Watanabe TK, Watanabe T, Yamazaki A et al (2017) Past summer upwelling events in the Gulf of Oman derived from a coral geochemical record. Sci Rep 7(1):4568

Weber J, Woodhead P (1970) Carbon and oxygen isotope fractionation in the skeletal carbonate of reef-building corals. Chem Geol 6:93-117

Weber JN, Deines P, Weber PH et al (1976) Depth related changes in the ${ }^{13} \mathrm{C} /{ }^{12} \mathrm{C}$ ratio of skeletal carbonate deposited by the Caribbean reef-frame building coral Montastrea annularis: further implications of a model for stable isotope fractionation by scleractinian corals. Geochimica Cosmochiica Acta 40:31-39

Yamazaki A, Watanabe T, Sowa K et al (2009) Reconstructing palaeoenvironments of temperate regions based on high latitude corals at Tatsukushi Bay in Japan. J Jpn Coral Reef Soc 11: 91-107

Yamazaki A, Watanabe T, Tsunogai U (2011) Nitrogen isotopes of organic nitrogen in reef coral skeletons as a proxy of tropical nutrient dynamics. Geophys Res Lett 38(19):L19605

Yamazaki A, Watanabe T, Tsunogai U et al (2016) A 150-year variation of the Kuroshio transport inferred from coral nitrogen isotope signature. Paleoceanography 31:838-846

Zinke J, Dullo WC, Heiss GA et al (2004) ENSO and Indian Ocean subtropical dipole variability is recorded in a coral record off southwest Madagascar for the period 1659 to 1995. Earth Planet Sci Lett 228(1):177-194 